\title{
A NON-MUSLIM PRESIDENT IN A MUSLIM STATE: ISLAMIC POLITICAL DISCOURSE IN CONTEMPORARY INDONESIA
}

\author{
Mujar Ibnu Syarif \\ University of Malaya, Malaysia \\ E-mail: mujarsyarif@yahoo.com
}

\begin{abstract}
Abstrak: Presiden Non-Muslim di Negara Muslim: Diskursus Politik Islam dalam Konteks Politik Indonesia Kontemporer. Artikel ini secara spesifik dimaksudkan untuk membahas secara kritis pendapat para cendekiawan Muslim Indonesia tentang kemungkinan non-Muslim menjadi presiden di Negara Republik Indonesia yang merupakan negara berpenduduk Muslim terbesar di dunia. Hingga detik ini, wacana Islam klasik tentang masalah ini cenderung terjebak dalam model analisis normatif yang terkesan rigid dan tidak toleran. Wacana ini, sampai batas tertentu, kurang dapat menghargai kondisi sosial, budaya, sejarah, dan kompleksitas politik masyarakat Muslim. Oleh karena itu, diskursus klasik mengenai masalah ini oleh banyak cendekiawan Indonesia kontemporer dipandang telah gagal merespons dinamika sosial-politik saat ini, terutama bila dilihat dari sudut pandang multi-kulturalisme dan demokrasi. Artikel ini membahas dimensi penting mengenai kepemimpinan non-Muslim di Indonesia yang sering dilupakan atau sangat jarang didiskusikan.
\end{abstract}

Kata Kunci: Islam di Indonesia, Presiden Non-Muslim, Otoritas Tuhan, Piagam Jakarta.

\begin{abstract}
A Non-Muslim President in a Muslim State: Islamic Political Discourse in Contemporary Indonesia. This article charts the political discourse amongst Islamic leaders regarding the possibility of a non-Muslim becoming President in Indonesia, the world's most populated Muslim state, an important issue but one that is only seldom discussed in an academic context. Until recently, classical Islamic discourse on this issue, which has generally rejected this possibility, had tended to be trapped in a normative model of analysis which today seems intolerant and rigid. This article contends that this discourse, to some extent, does not properly appreciate the complex social, cultural, historical and political realities of the Muslim community today. Indeed, many other contemporary scholars view this mode of discourse as failing to respond to the current social-political dynamic, especially those scholars coming at it from a multicultural democratic perspective. Perhaps most importantly, the legal reality-even though there is a reasonable degree of controversy surrounding it - which is that there is no criterion that the President has to be Muslim, is also rejected by this discourse.
\end{abstract}

Keywords: Islam in Indonesia, Non-Muslim President, God's Authority, Jakarta Charter.

\section{Introduction}

This article discusses the possibility of a Non-Muslim becoming President in Indonesia. From a theological point of view, this is a difficult issue because both the Qur'an and Sunnah, the two main sources of Islamic Law, contain both arguments that forbid Muslims from choosing Non-Muslim leaders and arguments that allow it. In aiming to determine whether or not being led my a non-Muslim President is permissible for Muslims, Islamic scholars have interpreted this contradictory information in a variety of ways.

At the moment, there is still skepticism regarding the possibility of a non-Muslim President conceptually, and discomfort of the prospect in practice. This is no

Received: 23rd January 2012, Revised: 16th May 2012, Accepted: 30th May 2012. wonder, as the regulations regarding this matter in Muslim majority countries are different to those in other countries. Most Muslim majority countries, including Tunisia, Algeria, Egypt, Syria, Pakistan, Bangladesh, Iran, Jordan and Malaysia, all apply regulations that the President or the head of state of the country must be a Muslim. Up until now, there have only been three Muslim majority countries that have been led by non-Muslim Presidents: Senegal, Nigeria and Lebanon. Although roughly $94 \%$ of its population is Muslim, from 1980 to 1988 Senegal was led by a Catholic President, Leopold Sedar Senghor. Nigeria, whose population also has more Muslims than it has Christians, saw Olusegun Obasanjo, who is Christian, serving as President of the country not just once but for three terms: 1976 to 1979,1999 to 2004 , and most 
recently from 2004 to 2007.

The most striking example, however, is Lebanon. In spite of an estimated $64 \%$ of its population being Muslim, Lebanon has been led by Christian Presidents since 1943. The reason for this is fairly simple; it has to do with al-Mitsâq al-Wathanî, the national pact established that year that says that the Lebanese President must be a Maronite Christian, the Prime Minister must be a Sunni Muslim, the House speaker must be a Shiite Muslim, the Defense Minister must be Druze Muslim, and the Foreign Affairs Minister must be Greece Orthodox Christian. This pact has been in effect and adhered to since 1943, so during this time the Lebanese President has never not been a Maronite Christian.

Contemporary opinion amongst Muslims, either in Indonesia or in other Muslim majority countries which still oppose non-Muslim Presidents, is in line with and influenced by a classical concept: that a country should be based on Islamic theology. In classical Sunni literature this country concept is called a caliphate, the head of state of which, the caliph, has two main tasks: firstly to maintain religion and secondly to manage the world

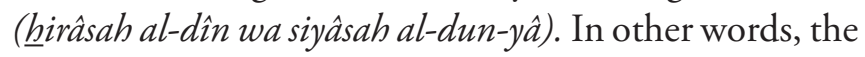
caliph is the one who holds power not only in religious matters, but also in political matters, where he has executive, legislative, and judicative powers. In terms of religion, he operates, amongst other things, as an imâm when performing mass prayers, as a leader of pilgrimage (Amîr al- $\underline{H} a j j$ ), and as a preacher of sermon at mosque, either during Friday, $\hat{\imath} d$ al-Fithr or $\hat{\imath} d$ al-Adh $\hat{a}$ prayers. However, while the social-political conditions now are far different to those of the classical era, it is the latter upon which contemporary opinion among Muslims about non-Muslim Presidency is based, even though such an era no longer reflects the current social-political situation. Therefore, if this opinion were to be based on a contemporary context, rather than a classical one, the question of whether or not a non-Muslim should be allowed to be able to become their President can be reconsidered.

\section{The Rules about Non-Muslim Presidency in Indonesia}

Since August 18, 1945, the requirement that the Indonesian President be Muslim has never actually been in place. Constitutionally speaking, non-Muslim citizens in Indonesia have the same political right to becoming President as Muslim citizens. However, following the issuing of the Presidential Decree on July 5, 1959, the issue of whether or not a non-Muslim could become the President has been the subject of bitter debate amongst politicians and Islamic leaders.

Historically in Indonesia there have been two groups contesting this debate. The first group believes the Presidential Decree of July 5, 1959 can be read as saying that only Muslims can become Indonesian President, and that this Decree automatically prevails. The second group disagrees that this true and therefore believe that non-Muslims are entitled to become President also.

Sociologically, the amount of Indonesian Muslims, who in total represent roughly $88 \%$ of the country (as of 2009), unwilling to vote for a non-Muslim Presidential candidate suggests that the country as whole is not willing to be led by non-Muslim President. Among other reasons, this is because the majority of Muslims, as reflected by the views of Nahdlatul Ulama (the largest Muslim Organization in Indonesia) for example, consider the Indonesian President to be the highest ruler or administrator in three areas: administration (binge kang sinuhun), military command (senopati hing ngalaga), and religious affairs (sayidin panatagama). Since these tasks correspond to those of the caliph, and the majority of contemporary Muslim opinion about Presidency is based on the caliphate, and obviously the caliph has to be Muslim, most Muslims believe that the Indonesian President and his vice President must also be Muslim. If not, their administration is considered illegitimate. As a consequence, the high ranking officials they appoint, including the penghulu (the officer in charge of recording marriage), are also considered to be illegitimate. If the penghulu is illegitimate, then so too is the marital status of a bride and bridegroom which the penghulu is involved in recording. Thus, if the religion of the Indonesian president were to be anything other than Muslim, the implications for Indonesian Muslims could be profound.

Based on the above reasoning, during the Dutch Colonial era Muslims did not want get married through the penghulu because it was the Dutch government-a non-Muslim administrator-who appointed him, making him illegitimate and thus unqualified to handle Muslim marital affairs. To resolve this issue, Muslims just appointed a person they trusted to be the wali hakim, the person who acts on behalf of the father of the bride to record the marriage.

In the Old Order regime, some Muslims did not only reject the notion of a non-Muslim President, but also that of a Muslim President who did not study in Islamic traditional schools (santri) and had not performed pilgrimage. Sukarno, Indonesia's first President, who was not educated in a traditional Islamic school, was considered by some Indonesian Muslims to therefore lack the required level of competence needed for the 
Presidency. To cover up this deficiency, a conference of Islamic scholars in Cipanas held on March 2-7, 1954, decided to give qualify Bung Karno's authority with the title of Walî al-Amr Dharûrî bi al-syawkah-emergency government administrator. Six years later, the title was re-inaugurated in Decision No.27 at the Nahdlatul Ulama Conference in Surabaya held on September 8-13, 1954.

At this conference, the title given to Bung Karno was formerly "Walî al-Amr Dharûrî dzû Syawkah". Besides bestowing the title, the Cipanas conference also decided that the tauliyah authority of anyone appointed by the President, including the authority of wali hakim, which according to tradition in some places should be appointed by Ahl al-Hall wa al'-aqd, was valid. But the term "dzûu syawkah" in the title was later corrected by Inyi' Candung, former Chairman of Central Sumatra Province's Islamic Law Court, to become "bissyawkah". According to him, this was because in all figh books, the meaning of the term "dzu syaukah" was always associated with "sulthân kâfirûn", the unbeliever sultan. Although Sukarno did not study in a traditional Islamic school, he was still a Muslim, not an unbeliever, hence the decision to correct the title.

After Sukarno performed pilgrimage and instructed to build the Baiturrahim mosque at the Merdeka Palace, the Islamic scholars at the State Islamic Institute (IAIN_now UIN) deemed it time to omit the term "Dharûrî bi al-syawkah" from Sukarno's title, changing it to just "Walî al-Amri". This title Walì al-Amri was then made official by MPRS (Provisional People's Consultative Assembly) through MPRS decision No. III/MPRS/1963 during the second MPRS General Session held in Bandung on May 15-21, 1963.

Discourse about whether or not non-Muslims should be able to become President formally began during the writing of Indonesian constitution in 1945, the second session of BPUPKI (Dokuritsu Zyunbi Tyosakai-a Japanese-organized committee for granting independence to Indonesia) held on July 10-16, 1945. During this session, both nationalist and Islamic groups agreed to a consensus that in the future Indonesia's freedom would be based on the basic principle of "Deity with an obligation to perform Islamic laws for its adherents". In addition, they also accepted Islam as the state religion, and that the Indonesian President must be a Muslim. What is more, they also accepted all Islamic sentences written both in the preamble and the body of 1945 Constitution bills.

It should be noted, however, that it seemed the consensus was not built on strong foundations. On August 18, 1945, one day after the Indonesian independence was proclaimed, this consensus was discussed again, with members of the Indonesian Independence Preparation Committee (PPKI), which had been established on August 7, 1945, chaired by Sukarno, held a meeting to review the consensus with an agenda of discussing some important amendments in the Preamble and the Constitution.

During the meeting, deputy chairman of PPKI Mohammad Hatta, extended four proposals for amendment as follows: (1) The word "Mukaddimah" was replaced by "Pembukaan"; (2) In the Preamble to the Constitutionm, a subordinate sentence, "Based on the Deity, with obligation to perform Islamic laws for its adherents" was replaced by "Based on a belief in the One and Only God"; (3) In Article 6 clause (1), "The President is a native Indonesian and Muslim," the words "and Muslim" were omitted; (4) Along with the second amendment above, Article 29 clause (1) became "The State is based on a belief of the one and only God", to replace "The State is based on the Deity and obligation to perform Islamic laws for its adherents".

The rationale of Hatta's decision to put forward these proposals was that they would serve to unite all Indonesians. The story goes that the advice of a young Kaigun (Japanese Navy) officer, whose name is forgotten, especially influenced this decision. His message was that unless some of the Islamic elements on the Jakarta Charter-such as the obligation to perform Islamic law for its adherents, Islam as the state official religion and the requirement that Indonesian President must be a Muslim - were amended, the Protestant and Catholic adherents, many of whom lived in the eastern part of Indonesia, would establish a new state.

So after holding that meeting for a few hours that afternoon, the PPKI agreed unanimously to introduce the amendments proposed by Hatta at the opening of the session into the Preamble and the Constitution. What is now widely known as the 1945 Constitution today includes these four aforementioned amendments. However, the hurried approval on some very important and divisive amendments triggered what General Chairman of the Masymi Islamic Party Prawoto Mangkusasmito called a "historische vraag" - a "history question" - where one's point of view on the legitimacy of these amendments, and thus the Constitution, depends on whose version of history one thinks is true. One version belongs to Endang Saifuddin Anshari, who notes that, of the nine people signing the Jakarta Charter the day before, only three people-Soekarno, Hatta, and Soebardjo-all secular Muslim nationalists, were involved in the amendment process of the preamble and 
the body of Constitutions on August 18, 1945. ${ }^{1}$ This meant that there wasn't a single Islamic nationalist who was involved in that amendment process. Therefore, if this is true, it is fair to say that in making these amendments independent of the six other signatories of the Jakarta Charter, the national group reneged on the compromise that had been reached with the Islamic group just a short time before. Believing this to be true, Islamic nationalists were left feeling as though they had been betrayed.

Another version, different to Anshari, belongs to Bahtiar Effendy, who notes that Hatta's proposals already had the backing of four Islamic figures, namely Ki Bagus Hadikusumo, Wahid Hasjim, Kasman Singodimejo and Teuku Muhammad Hasan. ${ }^{2}$ If we take what Effendy says to be true, then it can't be said that the original compromise had been redone as unjustly as Anshari claims, as the new, amended compromise was similarly reached on a common, if less formal, agreement between Islamic and secular parties.

\section{The History of Non-Muslim Presidency in Indonesia}

The potential of the country having a non-Muslim as President became a very real prospect and a hot topic of conversation amongst the public in the 1980s when it was reported that Benny Moerdani, a Catholic General and the Indonesian Armed Forces Commander at that time, was aspiring to become President. At first, only a small number of Moerdani's contemporaries knew of this aspiration. In the military, the first person to find out was Prabowo Subianto, President Suharto's son-inlaw who was also a special staff member of Moerdani's at the time. When Suharto himself learnt of Benny's ambition, through Subianto, he initially didn't believe him, but eventually changed his mind after receiving further confirmation from other sources. Moerdani was so angry at Subiyanto that he discharged him from Kopassus (the Army's special forces unit) and made him a military district commander (Kodim) of a far-flung location a long way from Jakarta.

One of the first people from outside the military to know of this aspiration was Moerdani's close ally, Abdurrahman Wahid, known simply as Gus Dur, who was asked specifically by Benny for his opinion on the matter. Moerdani's relationship with Gus Dur later became the subject of controversy when Gus Dur,

\footnotetext{
${ }^{1}$ Endang Saifuddin, Anshari, Piagam Jakarta 22 Juni 1945 Sebua Konsensus Nasional Tentang Dasar Negara Republik Indonesia (1945 1949), (Jakarta: Gema Insani Press, 1997).

${ }^{2}$ Bahtiar, Effendy, Islam dan Negara Transformasi Pemikiran dan Praktik Politik Islam di Indonesia, (Jakarta: Paramadina, 1998).
}

speaking at a seminar titled "Political Development in Indonesia" held at Monash University in Australia, was asked whether a non-Muslim could become Indonesian President, and who he thought the most appropriate future leader for the country was. In response, Gus Dur said that according to the Indonesian Constitution, a non-Muslim could become President, and one of the most appropriate future leaders would be Moerdani. This answer, to a very provocative question for Indonesian Muslims, caused a number of different reactions. While some saw the response as perfectly reasonable, since, as Gus Dur had said, the 1945 Constitution does state that a non-Muslim can become President in the future, others were angry at Gus Dur just for canvasing the idea. Others claimed that the comment was evidence that he had formed a coalition with Benny Moerdani and planned to nominate him as the Indonesian President. Others accused him of being non-Muslim henchman.

Later on, prior to the 1993 election, in addition to the United Development Party (PPP), four members of the Indonesian Muslim Scholars Association (ICMI) - Ismail Sunny, Nurcholish Madjid, Sri Edi Swasono, and Muslimin Nasution-frequently condemned Gus Dur's support of Moerdani's to replace Soeharto as President. During a private discussion with a US diplomat, when these four were asked for their opinion on the prospect of Moerdani becoming the next President, Nurcholish said that even though Gus Dur-a prominent Muslim—seemed to approve his candidacy, he still thought that Muslims would not accept it. Nurcholish's opinion on this matter was gotten hold of by the media when Sunny leaked it to them soon after.

As usual, in facing these reports Gus Dur was very calm in front of the media. According to Gus Dur, certain people, including Lukman Harun of Muhammadiyah, who had contributed to the gossip about his support for Moerdani, had simply misunderstood him. His statement in Australia about Benny did not necessarily mean that he wanted him to supplant Suharto as President. Rather, it was merely meant to educate an Australian audience about Indonesian politics, and that constitutionally speaking Moerdani, as a nonMuslim, had equal rights to the Presidency as a Muslim. Besides, the fact that the pair were already colleagues meant that his support for Moerdani was perfectly understandable.

However, Gus Dur realized that most Muslim leaders, particularly modernists, didn't really trust Moerdani. The main reason for this was due to the 1984 Tanjung Priok Incident, in which, at Moerdani's order, Islamic protesters were killed in a demonstration 
in Jakarta. Nevertheless, because Gus Dur felt that if he wasn't loyal to Moerdani he might lose his job as leader of Nahdlatul Ulama (NU), he remained supportive of him, even though secretly Gus Dur didn't approve of his friend's violent streak. In fact, for Gus Dur, his relationship with Benny was reportedly more one of mutual benefit than one of friendship. Gus Dur's relationship with Moerdani meant that whenever he was detained by the police-eight times in total when he was campaigning for PPP-Moerdani immediately released him. Plus, his relationship with Moerdani attracted the attention of the elite, meaning greater exposure for himself and the NU, and enabled him to gain access to the world of the ruling regime. In a society tightly controlled by the military, even a little support from one of the military's high ranking officials was not only useful, but also necessary if one wanted to play an important part in Indonesian politics. Meanwhile, Moerdani's relationship with Gus Dur, with both men similarly concerned about the threat militant Islam presented to a harmonious Indonesia, was viewed as serving as a gateway to the world of politics.

Some also viewed Gus Dur's statement in Australia as being aimed at upsetting the relationship between Suharto and the military, which was, at that time, under Moerdani's command. Later on, it was revealed that the relationship between Suharto and the military was starting to sour, with Moerdani secretly starting to oppose Soeharto. When Soeharto realized that the military's support for him was diminishing, he responded with a move to balance military power by changing his approach in dealing with conservative Muslims. This was illustrated most categorically in 1990 when the Indonesian Association of Muslim Intellectuals (ICMI) was set up. Several months before the ICMI's official inception, Suharto clearly stated his wish to sponsor it. The organization has had a close association with Golkar, Suharto's party, ever since. In addition to substantial financial support from Suharto, he also appointed senior minister B.J. Habibie as an official chairman.

Conservative Islamic scholars were delighted about Soeharto's support for ICMI, especially those who had been involved in starting ICMI who had previously been active in Masyumi, a major Islamic Political Party in Indonesia, but whose efforts to try to revive their party had previously been rejected by Suharto. Suddenly, in feeling as though they had gone from the state's enemy to its friend, it finally felt like their prayers had been answered.

Through his support of ICMI, Suharto succeeded in making militant Muslims go from criticizing him to cooperating with him. It was also with the help of the ICMI that he garnered the support of almost half the country's Muslims, which contributed to his being reelected in 1993. However, even though political tension had subsided after the election, Suharto still considered that Gus Dur threatened to undermine his relationship with the military, which was cause for concern as he believed the military had the potential to topple him from the Presidency. With Suharto already having demoted Moerdani from Armed Forces Commander to Defense Minister in 1988-replacing him with Try Sutrisno-before his term had ended, in 1993 he was booted from cabinet altogether, confirming in no uncertain terms Suharto's feelings towards him.

In 1998, early on in the reform era, the press reignited the issue of non-Muslim Presidency with the circulation of a photograph picturing Megawati devotedly engaged in Hindu ritual. A.M. Saefuddin, the then Minister of Food and Horticulture, utilised this image to suggest that since Megawati was presumably Hindu, given Indonesia's Muslim majority population he would be a better choice as President. Afterwards, Saefuddin said in a press conference that he did not mean to offend nonMuslim Indonesians, yet this did not stop the Balinese Hindus from being furious at him. In a demonstration broadcast on television, Balinese Hindus were seen hanging Saefuddin's dummy, insisting he apologize and resign from his position.

Even though he did not resign from his position, Saefuddin did have to apologise to the Hindus for his controversial remarks, which were deemed to have humiliated them by downgrading them to second class citizens. Megawati, for her part, aimed to get her candidacy as Indonesian President back on track with what was dubbed a "political hajj pilgrimage". Six years later, the issue re-emerged when, for the first time in modern Indonesian history, the General Chairman of Partai Damai Sejahtera, Ruyandi Hutasoit, a Christian, ran for President in the 2004 Presidential Election. Again, this event was met with conflicting views. On the one hand, Hutasoit's supporters thought his candidacy was constitutionally legitimate. On the other hand, while resigned to that fact, those who opposed it argued that because Indonesia itself was predominantly Muslim, this forbade a non-Muslim from becoming President. The journalists of Sabili took the latter stance particularly aggressively. The front cover of the April 23, 2004 edition of the magazine declared "Tolak Presiden Salib" - "Reject Christian President", a nonetoo-subtle reference to Hutasoit. 


\section{Scholarship about Non-Muslim Presidency in Indonesia}

The requirement which states that the Indonesian President must be Muslim was removed from the Constitution on August 18, 1945, as mentioned earlier. Nevertheless, there is still difference of opinion amongst political leaders as to whether or not a non-Muslim Indonesian can become President. Amongst those who oppose non-Muslims from becoming President, there are at least three reasons that underpin this stance. The first reason, as advocated by Anshari and Ali Yafie, is that the Jakarta Charter (Piagam Jakarta) states that the Indonesian President must be Muslim, and since the 1945 Constitution is inspired by the Jakarta Charter, so it follows that this is a legitimate basis for the President having to be Muslim. ${ }^{3}$

The second reason, as put forth by Prof. Ibrahim Hosen, is that the Republic of Indonesia actually belongs to an Islamic State (Darul Islam), due to its predominantly Muslim population. In an Islamic State (Darul Islam), Hosem argues that a waliyyul amri (President) and his Vice must be good Muslims. Furthermore, Hosen argues that in addition to political affairs the head of state is also responsible for the management of religious and spiritual matters, so in order to carry out both these duties, unless he is Muslim he is unqualified for the role. Hosen says that to support the candidacy of non-Muslims as waliyyul amri is in fact to disobey the teachings of their religion. He accuses Islamic leaders who do take this stance of probably only doing so in order to position themselves for a shot at ministerial cabinet or a similar role, and that they shouldn't be considered as ulamas (Islamic Scholars) by the general public, but if they are to be then they should only be considered as ulama sî̀ (confused ulemas).

Hosen's view is in line with and influenced by the concept that the state should be based on classical Islamic ideology, rather than any other ideology, such as nationalism. But today, according to Munawir Sjadzali, this classical thinking is no longer relevant, as the state is mostly sustained by national principles rather than religious ones. ${ }^{4}$ According to Robert N. Bellah, if there is an appropriate Islamic model for a nation state today it is the Medina Charter, the social-political order established by Prophet Muhammad in Medina and developed by al-Khulafa al-Rasyidun. Munawir calls on Muslims in this current contemporary era to subscribe to this charter, as it guarantees equal rights and

\footnotetext{
${ }^{3}$ Interview with Ali Yafie, Jakarta, March 4, 2004.

${ }^{4}$ Munawir, Sjadzali, "Kembali ke Piagam Madinah", in Politik Demi Tuhan: Nasionalisme Religius di Indonesia, (Bandung : Pustaka Hidayah, 1999).
}

obligation between the citizens and the state regardless of religion.

The third reason, expressed by Didin Hafidhuddin, is that it is convention that the Indonesian President is Muslim. ${ }^{5}$ Hafidudhin also argues that irrespective of one's normative stance, it is unlikely that a non-Muslim could become President for theological, sociological and psychological reasons. Theologically, Indonesian Muslims are obliged to choose, and have chosen Islamic leaders throughout the country's history. Sociologically and psychologically, Hafidhuddin says since most Indonesians are Muslim, and most Muslims assume that a Muslim leader would respond to their aspirations more favorably, a leader of any other religion simply wouldn't be able to get the numbers required to become elected. As long as Indonesian Muslims act in strict accordance to their faith, Hafidhuddin asserts, this will hold true. Said Aqiel Siradj agrees with this, but unlike Hafidudhin thinks that just because it is unlikely that non-Muslim will become President, doesn't mean that he or she shouldn't be able to become President ${ }^{6}$.

Those in favor of non-Muslims being able to become President are non-Muslim scholars like J.T.C. Simorangkir (Protestant) and B. Mang Rey Say (Catholic) and some Muslims like Hasyim Muzadi, Ahmad Syafi'i Ma'arif and Gus Dur. They point to at least three main reasons as to why a non-Muslim should be able to become Indonesian President. The first reason, as drawn upon by Simorangkir and Mang Rey Say, is that the Jakarta Charter is not its binding legal source. Furthermore, Ruyandi Hutasoit adds that just because the Jakarta Charter was mentioned again in the Preamble to the July 5, 1959 Presidential Decree, doesn't mean that the requirement that the President must be Muslim was suddenly automatically revived. ${ }^{7}$ If we accept this reasoning, then we have to accept that the Jakarta Charter, which at one point, though not anymore, said that the President had to be Muslim, does not effect the prevailing 1945 Constitution, even though there is currently nothing in there specifically saying that the President doesn't have to be Muslim.

Similarly, Ahmad Syafi'i Ma'arif states that although most Indonesians are Muslim, this does not mean that minority groups do not have the right to be President. ${ }^{8}$ As long as a candidate from a minority group is able to win a democratic Presidential election, it is possible for them to become President. However, if we look at the United States of America, where the majority of its

\footnotetext{
${ }^{5}$ Interview with Didin Hafidhuddin, Bogor, May 72005.

${ }^{6}$ Interview with Said Aqiel Siradj, Jakarta, May 9, 2005.

${ }^{7}$ Interview with Ruyandi Hutasoit, Jakarta, May 25, 2005.

${ }^{8}$ Interview with Ahmad Syafi'i Ma'arif, (Jakarta, May 17, 2005).
} 
population is Protestant, it has seldom seen a citizen from a minority religion be elected as President. An exception to this rule, John F. Kennedy, a Catholic who became President in 1960, was killed before he had ended his term in office in 1963. Ma'arif says that India, with a majority Hindu population, is the exception, with some Presidents from the Muslim minority. So far none of them have been killed in office.

Saefuddin says that the probability of a non-Muslim becoming Indonesian President is about the same as that of a Muslim becoming US President, which, after 230 years of democracy, has yet to happen, even though the US unambiguously separates church and state and the US constitution does not forbid Muslims or anyone of any other religion from becoming President. Similarly, in Europe, given that the majority population is not Muslim and is unlikely to want to vote for a Muslim, it is not that a Muslim is not allowed to become President but simply that it is unlikely that it would happen. Even theologically, Hasyim Muzadi notes that although there are some verses in the Qur'an, for example Verse 28 of Surah Ali Imran, which forbid Muslims from electing a non-Muslim leader, the Qur'an has two types of prohibitions-absolute and non-absolute-so it is important to see what type of prohibition applies to non-Muslim leadership. ${ }^{9}$ An example of an absolute prohibition is to make a non-Muslim an Imam in a mass prayer. Meanwhile, a non-absolute prohibition is, among others, electing a non-Muslim President, which means that in some circumstances this can be a legitimate course of action, even in a Qur'anic framework.

The second argument as to why theoretically a nonMuslim can become President is because Indonesia is not an Islamic State and in the Constitution there is nothing prohibiting a non-Muslim from becoming one. As Gus Dur points out, Article 6 clause (1) of the Constitution stipulates that every Indonesian citizen, regardless of their religion, has the same right to become President. While it is understandable that most of the time the President will be Muslim, this does not change the constitutional fact that there is always the possibility that he or she will belong to a different religion. Again, in the case of the US, while it is unlikely that a Muslim will become President, their right to this title is shared by every other American, whatever their ethnicity, religion or sex, and American Muslims welcome this fact.

However, unlike Saefuddin and Hafidhuddin, Gus Dur predicts that a non-Muslim Indonesian President is not outside the realm of possibility in the future. Ruyandi Hutasoit, Theo L Sambuaga, and Muchtar

${ }^{9}$ Interview with Hasyim Muzadi, Jakarta, May 9, 2005.
Pakpahan agree. Hutasoit, for instance, says that a time will come when this happens in Indonesia, as it has in both the recent past and the distant past. The recent Christian Presidency in Nigeria, and the example of the Prophet Yusuf in Egypt, a non-Egyptian native and from a minority group, succeeding the King Pharaoh as the country's ruler, shows that nothing is impossible with God's permission.

The third reason, in rebuttal of that of the opposing group, is that it is not true that all Indonesians believe that Muslim Presidency is conventional, or that even if this were true it should determine whether the President should be anything other than Muslim. The fact that Ruyandi Hutasoit, a Christian from Batak ethnic group, was nominated as the PDS Presidential candidate for the 2004 Presidential election, runs counter to the convention argument. PDS Secretary General Denny Tewu asserted at the time that in nominating $\mathrm{Mr}$. Ruyandi, the view that the Indonesian President must be Muslim and Javanese had sought to be eliminated and replaced with the view that the President should simply be the best and most capable person for the job. At the very least, this view indicates the faith that contemporary Indonesians, Muslim or otherwise, feel the same way.

\section{Closing Remarks}

So which view is correct? Should a non-Muslim be able to become President or not? Constitutionally, it is clear that members of other religious groups-Hindus, Buddhists, Christians, Catholics, and even members of communities with no formally recognized religion-are just as entitled to the Presidency as Muslims, despite the latter representing the majority of the population. Although Muslim people may feel obliged to reject any non-Muslim leader, the laws of the state concerning this matter, to which all Indonesians abide, unlike Islamic law to which only Muslims are obliged to abide, do not equate to those of any one religion, which in Indonesia Islam is but one of many. Since the view that prohibits non-Muslims from becoming President has not been approved through the legal corridor, it is therefore not legally binding. Neither the 1945 Constitution nor Law on Presidential and Vice Presidential Election has a single article which stipulates that the President must be Muslim. The exclusion of the legal requirement that says that the President must be a Muslim is in Article 6 clause (1) of 1945 Constitution and Article 5 of Presidential and Vice Presidential Election (Law No.42/2008). As long as this holds, the principle of "istish $\underline{h} \hat{a} b$ " - which in Islamic law study (ushûl fiqh) means a law that is valid until a new law supplants 
it-applies. To deny the legitimacy of the legal corridor and treat faith as grounds for rejecting a non-Muslim President is not only a violation of the rights of all nonMuslim Indonesian citizens, but in fact to also deny istish $\underline{h} \hat{a} b$ itself. []

\section{Bibliography}

Anshari, Endang Saifuddin, Piagam Jakarta 22 Juni 1945 Sebuah Konsensus Nasional Tentang Dasar Negara Republik Indonesia (1945 - 1949), Jakarta: Gema Insani Press, 1997.

Effendy, Bahtiar, Islam dan Negara Transformasi Pemikiran dan Praktik Politik Islam di Indonesia, Jakarta: Paramadina, 1998.

Esposito, John L, Islam dan Politik, translator M. Joesoef Syamsuddin, from Islam and Politics, Jakarta : Bulan Bintang, 1990.

Interview with Abdurrahman Wahid, Jakarta, May 18, 2005.

Interview with Abdul Gani Abdullah, Jakarta, April 9, 2005.

Interview with Ahmad Syafi'i Ma'arif, Jakarta, May 17, 2005.

Interview with Didin Hafidhuddin, Bogor, May 7 2005.

Interview with Hasyim Muzadi, Jakarta, May 9, 2005.

Interview with Ruyandi Hutasoit, Jakarta, May 25, 2005.

Interview with Said Aqiel Siradj, Jakarta, May 9, 2005.

Interview with Azyumardi Azra, Jakarta, June 6, 2003.

Interview with A.M. Syaefuddin, Bogor, July 28, 2003.

Interview with Ali Yafie, Jakarta, March 4, 2004.

Isre, Moh. Saleh (ed.), Tabayyun Gus Dur Pribumisasi Islam Hak Minoritas Reformasi Kultural, (Yogyakarta: LKIS, 1998), 1st edition.

Khallaf, Abd al-Wahhab, al-Siyâsah al-Syar'iyyah aw
al-Nizhâm al-Daulah al-Islâmiyyah fi al-Syu'ûn alDustûriyyah wa al-Khârijiyyah wa al-Mâliyyah, alQâhirah : Dâr al-Anshâr, 1977.

---.-----, Ilm Ushul al-Fiqh, al-Kuwait : Dâr alQalam, 1978.

Mahendra, Yusril Ihza, "Koalisi Murni Hanya dalam Sistem Parlementer", in Sabili, No. 19, 7 April 1999.

Masyhuri, A. Aziz, Masalah Keagamaan Hasil Muktamar Dari Munas Ulama NU Kesatu (1926) Sampai Dengan Ketigapuluh (2004), Jakarta : Qultum Media, 2004.

Noeh, Zaini Ahmad, "Waliyul Amri Dharuri Bissyaukah antara Fakta dan Politik", in Panji Masyarakat, No. 456, year XXVI, 29 Rabi'ul Akhir 1405 H / January 21, 1985.

Panji Masyarakat, No. 13, tahun I, Juni 2003, dan No. 645, 28 Zulhijjah $1410 \mathrm{H}$ - 10 Muharram $1411 \mathrm{H}$ / July $21-31,1990$.

Parera , Frans M. and Koekerits, T. Jakob, (ed.), Gus Dur Menjawab Perubahan Zaman, Jakarta : Kompas, 1999.

Reformata, $10^{\text {th }}$ Edition, year I, January 2004.

Ridhwan, Affandi, "Sambutan Ketua Dewan Dakwah Islamiyyah Indonesia", in Amandemen UUD 1945 Tentang Piagam Jakarta, Jakarta : Media Dakwah, 2000.

Sjadzali, Munawir, "Kembali ke Piagam Madinah", in Politik Demi Tuhan : Nasionalisme Religius di Indonesia, Bandung: Pustaka Hidayah, 1999.

Suara Pembaruan, Monday, March 15, 2004.

UUD 1945 Hasil Amandemen dan Proses Amandemen UUD 1945 Secara Lengkap (Pertama 1999-Keempat 2002), Jakarta : Sinar Grafika, 2002.

UU No. 23/2003 Tentang Pemilu Presiden dan Wakil Presiden.

UU No. 42/2008 Tentang Pemilu Presiden dan Wakil Presiden.

Zein, Kiplan, Konflik dan Integrasi TNI-AD, Jakarta : Institute for Policy Studies, 2004. 